\title{
Vulnerability among young people after exposure to alcohol
}

\begin{abstract}
This is an exploratory research with a quantitative approach that aimed to determine the vulnerability of young people after exposure to alcohol. The study included 108 young people attending bars in the vicinity of a private university in São Paulo. Among the participants, $50.93 \%$ were male and $49.07 \%$ female, aged between 18 and 29 years. Most were single, Catholic, childless, with employment and higher education students. The alcohol consumption was reported by $100 \%$ of men and of women $79.25 \%$. The reasons for consumption were animation and celebration. Regarding the vulnerability after exposure to alcohol, $45.37 \%$ reported alcohol amnesia, $36.11 \%$ said they kept unprotected sex and $14.81 \%$ suffered traffic accidents. It is concluded that the pattern of high and frequent consumption of alcohol are present in the university, requiring a different approach to nursing in promoting health.
\end{abstract}

Keywords: alcohol-related disorders, alcohol drinking in college, health vulnerability
Volume 3 Issue 6 - 2017

\author{
Ana Carolina Albiero Leandro da Rocha, \\ Tatiane Alves de Brito \\ School of Nursing, Universidade Paulista, Brazil
}

Correspondence: Ana Carolina Albiero Leandro da Rocha, School of Nursing, Universidade Paulista, Brazil, Email acalrocha@gmail.com

Received: July 28, 2017 | Published: September 28, 2017

\section{Introduction}

Alcohol abuse is a public health problem because it is one of the major risk factors for premature deaths, traffic accidents, suicides, violence, among others. ${ }^{1}$ Data from the World Health Organization (WHO) show that abusive consumption of alcoholic beverages is increasing worldwide, with a high prevalence among young people. ${ }^{2}$

Brazil has about 50.2 million young people between the ages of 15 and 29 , corresponding to $26.4 \%$ of the population. ${ }^{3}$ The use of alcohol among young people has been a common and frequent practice, present in celebrations, meetings, family environment and others. ${ }^{4}$ Despite laws that provide for the prohibited sale of alcoholic beverages for minors under 18 , access is facilitated among minors. ${ }^{5}$

Youth is considered a phase of transformation between adolescence and adulthood, moment of preparation, duties and responsibilities. People of the same age group can present different attributes, due to the personality and particularity of each one, challenges, risks and vulnerabilities. ${ }^{6}$ The present study aims to verify the profile, motivations and vulnerability after alcohol exposure of young people in bars around a private university in São Paulo, Brazil.

\section{Objective}

To verify the motivation and possible vulnerability among young people who use alcohol.

\section{Methodology}

This is an exploratory study with a quantitative approach. The research was carried out in bars around a private university in the city of São Paulo. We interviewed 108 youngsters from 18 to 29 years of age who accepted to participate, according to the ethical precepts of the research. The youngsters answered a questionnaire with 17 objective questions about alcohol use. The data were analyzed by descriptive statistics.

\section{Results and discussion}

A total of 108 youths participated in the study, 50.93\%(55) males and 49.07\%(53) females, aged between 18 and 29 years. Mostly single, childless and declared themselves to be Catholic. Regarding the employment relationship in the research period, $81.81 \%$ of the young people were working in the formal market. Regarding income, young men reported income equal to or higher than 3 minimum wages, even with incomplete higher education. This income range was only to women with full education.

As for schooling, because it is a research carried out in the surroundings of a university, it was observed an expressive part of the student of higher level. The sample of young men was composed of engineering students $(32,25)$, administration $(26,47)$, nursing $(8,82)$, law school $(8,82)$ and publicity $(8,82)$. Other courses had no more than $5 \%$ of citations.

Week-end consumption was reported by 60 participants and the use of four to six times per week by 41 , consuming up to 4 doses per occasion. The bars were located five to ten kilometers away from the residence. Regarding the means of transportation, $70.9 \%$ of men used private cars, while women, $41.5 \%$ use car and the same proportion for public transportation.

As for the motivation to use alcohol, the young people responded as many reasons as they wanted, and most of the reports were for animation and celebration. The use of alcohol among young people has been a common practice and is often present at celebrations, meetings, family environment, and others. Despite the ban on the sale of alcoholic beverages for children under 18, their access is facilitated among adolescents. ${ }^{4}$ After exposure to alcohol, 49 participants reported alcoholic amnesia, 39 said they had unprotected sexual intercourse and 16 suffered traffic accidents. Accidents after consumption of alcoholic beverages, increase significantly. ${ }^{7}$ The nurse should seek knowledge about alcohol use, which will provide a vision regarding abusive use, and can provide quality care. ${ }^{8}$

\section{Conclusion}

The recreational use of alcohol is present in the daily life of young people, with frequent use and patterns of high consumption. Bargoers around the university were mostly young, single, university, 
with employment in a private economy and income between two and three minimum wages. As for the academic course of the participants of the research, several courses were observed, with engineering and administration relevance for men and nursing and pedagogy for women. Among the motivation for the use of alcohol are celebrations and animation. Regarding vulnerability after exposure to alcohol, we observed the use of tobacco, alcoholic amnesia, unprotected sexual intercourse and traffic accidents.

Responsible use of alcohol in any age group is a challenge for society due to various cultural, advertising, psychological and organic factors. Nurses and other health professionals are of fundamental importance in providing quality care, by encouraging young people to perceive the potential vulnerabilities of alcohol use and to make them aware of the harm caused by their abusive use.

\section{Acknowledgements}

None.

\section{Conflict of interest}

The author declares no conflict of interest.

\section{References}

1. Ministério da saúde. Secretaria nacional antidrogas. I Levantamento nacional sobre os padrões de consumo de álcool na população brasileira. Brasil: Springer; 2007.
2. Moura, Erly C. Consumo de bebidas alcoólicas na população adulta brasileira: características sociodemográficas e tendência. Rev Bras Epidemiol. 2011. p. 61-70.

3. Instituto Brasileiro de Geografia e Estatística. Síntese de indicadores sociais das condições de vida da população brasileira. Brasil: Springer; 2015.

4. Pechansky, Flávio. so de álcool entre adolescentes: conceitos, características epidemiológicas e fatores etiopatogênicos. Rev Bras Psiquiatr. 2004;26(Suppl 1):14-17.

5. Lei $n^{\circ} 12.852$, de 05 de agosto de 2013 e legislação correlata. Estatuto da Juventude $2^{a}$ edição. Brasil: Springer; 2015.

6. Silva, Roselani S. Política Nacional de Juventude trajetória e desafios. Caderno CRH, Salvador. 2011;24(63):663-678.

7. Abreu, Ângela MM. Uso de álcool em vítimas de acidentes de trânsito: estudo do nível de alcoolemia. Rev Latino-Am Enfermagem. 2010. p. $513-520$.

8. Acauan, Laura. Alcoholism: a new challenge for the nurse. Esc Anna Nery. 2008;12(3). 